\title{
Proceeding
}

8th INSHS International Christmas Sport Scientific Conference, 5-7 December 2013. International Network of Sport and Health

Science. Szombathely, Hungary

\section{Internal and external political function of sport}

\author{
ONDŘEJ ŠTAUD \\ Faculty of Sport Studies, Masaryk University, Brno, Czech Republic
}

\begin{abstract}
Štaud, O. (2014). Internal and external political function of sport. J. Hum. Sport Exerc., 9(Proc1), pp.S359S368. Work is based on two pairs of case studies; the first pair is focused on an analysis of the internal political function of sport and the second pair is focused on the external political function of sport. All of the case studies will be applied to national teams as well as club sports. In the first two cases, we will analyze the internal role of sport in two different situations; in former Yugoslavia in the early nineties and also in Spain. We will analyze their separatist crises and the various possibilities of solving these crises through sport. In the other two cases we will present two situations, which will demonstrate the political effect of sport from an international point of view. In the first case we will examine the fate of the Czechoslovakian athletes in the late sixties and their attitudes toward competition with the former Soviet Union. The second case will be devote to the former Soviet states that through sport either gradually gained prestige in the international sphere or vice versa incurred losses, as was the case for Russia. The aim of this work is to show how sport can shape the political situation both outside of the borders as well as within a country. The primary method used was historical analysis of sports as well as analysis of the internal political situation in countries described and their international position in the given geopolitical situation. In the first example of the former Yugoslavia it is clearly visible how clubs sports as well as national-level sports started the whole process of disintegration of the country and helped establish the newly formed country. The second case takes us into a completely different situation in Spain where sport is supposed to be instrumental in keeping together this multinational kingdom. The second part outlines the issue of the political function of sport internationally. The first case is Czechoslovakia, where hockey fights with the Soviet Union became a powerful ventilation of resistance to the usurper, despite the ruling communist elite. In the second example analyzes the example of Russia and its retreat from the sporting glory after the collapse of the Soviet Union and the need for rebirth of sporting achievements as a political promotion of the country. The results are mainly a description of the structure of sporting events and their subsequent impacts on the happenings both inside and outside of a country and its appearance in front of other states. Key words: POLITICS, SPORT, CRISES IN SPORT.
\end{abstract}

Corresponding author. Faculty of Sport Studies, Masaryk University, Brno, Czech Republic/ Kamenice 5, 625 00, Brno

E-mail: o.staud@seznam.cz

8th INSHS International Christmas Sport Scientific Conference, 5-7 December 2013. International Network of Sport and Health Science. Szombathely, Hungary.

JOURNAL OF HUMAN SPORT \& EXERCISE ISSN 1988-5202

(C) Faculty of Education. University of Alicante

doi:10.14198/jhse.2014.9.Proc1.21

VOLUME 9 | Proc1 | 2014 | S359 


\section{INTRODUCTION}

Direct connection of sport and politics is not a novelty in a theoretical sociological research. Sport has been used several times for political purposes since the establishment of modern sport, whether we are talking about the period of totalitarian governments in thirties and forties, through the Cold War to the current sports geopolitical struggle where political and economic goals blend together (Coakley, 2001). The aim of this article is to analyze case studies of the political functions of sport and the impact of sporting successes or failures on the population of the country and the related political situation.

For a better understanding, we should clarify the general issues level at the very beginning. It is necessary to note that all stems from the viewer's interest in sports. Sport enters wider social awareness in the form of spectatorship. It becomes part of mass culture and creates the preconditions for its economic and political use. On the other hand, it is possible to observe other forms of social responses in particular in case of success. It is a formative influence, which shows that major sporting achievements have helped to shape the attitude of population to the sport as a social phenomenon. In such cases, especially sporting success reinforces the sense of social belonging and stimulates the experience of sharing success.

In addition, we can observe the effect of success in major sporting events like the Olympics or world championships in major sports, especially on children and youth, which is modified by their attitude to the sport as possible sphere of active operation. Sports practice demonstrates an increased interest in sports which achieved success in such an important competition. Prevailing attitude in immediate social surroundings and socially created conditions for the development of evoked interest decide whether the interest is episodic or long-term. We should also list some arguments to defend the direct intervention of government in sports as well as arguments defending association of government and the national sphere of professional sports.

Arguments for the relation of sport as a factor of forming the nation by Professor Grant Jarvie:

- Sport is a form of cultural nationalism

- Sport is a substitute for political nationalism

- Sport can contribute to ethnic as well as civic forms of rationality, many of them can be fictitious, alleged or selective

- Sport helps with the process of national recognition

- Sport provides a safe way to express emotions for a frustrated societies or nations

- Sport helps to build national identity and patriotism

- Nowadays the denial of national sports represents bestowed national sentiment in specific sports clubs such as FC Barcelona

- National support for sport was a natural reaction against the pressure to create a global, internationalist sport

- Sport contributes to build national consciousness (Jarvie, 2005).

For completeness we add the view of Jay Maguire who claims that the recent transformation of nations has also been affected by sport which has been used as a tool for integration and mediated acceleration of the building of the nation. Here are a few comments on this topic:

- Sport is inherently conservative and helps to consolidate officiality of the state, nationalism and patriotism

- Sport has some natural properties and may become a potential instrument of national unity and integration 
- Sport contributes to specific political struggles, some of which are closely connected to nationalist politics and populist nationalist struggles

- Sport is often involved in the process of nationalism as a natural response to the development of dependence and instability

- Sport contributes to the search for identity, which can manifest itself in mythology, national legends and the public exhibition of national flags as well as presentation of the national anthem (Maguire, 2002, 2005).

One of the most important social aspects of success in sports is a promotional effect resulting from the attraction of major sporting events for the predominant part of the population that is due to the geographic location and tradition of the sport in the country. Due to this attractiveness, information of sports successes or failures is spreading and being experienced in the places where other type information is difficult to enforce. The reality is perceived and socially accepted with the effort to use it on a local and national level. It uses the undeniable fact that the peak performance and success cannot be achieved without social and economic support at the local and national level. Sporting achievements and information about them are the undisputed socio-political charge. Sporting achievements were in different historical periods associated with the opportunity to present the successful social and economic systems within which the successful athletes lived (Slepičková, 2010). Sporting successes in particular have their social dimension with differentiated meanings to different social subsystems. These successes are part of social life, which often has political implications at national and international level. Major sporting events, which are among the world's most watched events, can serve as an example. Success in these sports competitions is published as the "national interest" and it is given widespread attention in the media. It is subject of interest to the political sphere as well as representatives of the state. Thus we return to the question of why the state needs such promotion. What is the predictive value result when economically backward state defeats more advanced state or when the state with smaller expanse defeats the state with much larger expanse? Does that indicate that the country has better system of physical education or perhaps that one nation is more physically developed? These mechanisms relate rather to the field of international relations, the internal political situation is different.

If we focus on the framework of national political events when sporting success spontaneously influenced political events, it is often quoted the case of trying to force "political coup" in Constantinople in 532. The stimuli were the successes and failures of individual stalls in the chariot races. These stables were an expression of the effort to present specific groups with the interest of a club with a link to the power structure of the society (Slepičková, 2010). This event demonstrates, although dated to the sixth century, how significant was the influence of actual sporting successes or failures, when the audience was spontaneously experiencing the socio-political events in each polity. The significance of the impact of sports success on politics is limited by the overall economic and political situation in individual countries. It may trigger potential changes in the politically unstable situation.

Most of the sporting success in politics is purposefully used to increase political interference prerequisite for achieving it. Example is the situation before the World Cup in Italy in 1934. Immediately prior to the start of the championships two South American players were granted citizenship on the direct intervention of Mussolini. The subsequent success was presented as a success of the political system, which has become a top representative (Slepičková, 2010). In this match in Rome the home team defeated Czechoslovakia and the championship foreshadowed Olympic Games in Berlin two years later (Cuhra, 2006). A similar example, like naturalized Italian football players, happened at the 1936 Winter Olympics in GarmischPartenkirchen, where the winning team of Great Britain was formed by the majority of players participating 
for Canada in the past. Again we could say that Great Britain wanted to shine before its nation and strengthen its position as colonizer while showing the Germans their superior athletic abilities (Canadian Olympic Team, 2013). Although these two examples are more related to the other delicate issue multiculturalism in sport.

The situation that took place before and during the football World Cup held in Argentina in 1978 was undoubtedly interesting. The success of the home team was considered "the national interest" by representatives of the state that could help to calm the political situation including covering up the persecution of the opponents of regime. Thousands of people have disappeared in Argentina at that time. Political intervention also took place to ensure the success of the home team. Before the match with a team of Peru (which home team had to win with high enough difference), state financial loan and also food aid were promised to Peru. Considerable victory in this match (6:0 for Argentina) was presented as a success of the politics of the ruling military dictatorship by the local media as well as by political leaders. Dictator Francisco Franco used the successes of Real Madrid on the international football scene in the same way for the presentation of his political regime and also as an example of the success of his government in the field of sport (Budd, 2004). In this context, we must also recall the situation in socialist Hungary, who boasted to incredible sports results. Hungary was called a "sports nation" and society accustomed to the outstanding achievements. The state of society has also been instrumental in easing local political situation. However, sporting achievements in this country reflected the marginalization of physical health of its citizens, who were in many cases strangers to the active sport (Gál, 2011).

Athlete's successes in former Czechoslovakia were given the same significance like it was in Hungary. The success of the existing political system (e.g. success of Emil Zátopek at the Olympics). Sporting achievements and their connection to the existing socio-economic system were used to enhance the emotional experience of population with a successful athlete, sports team as a representative of the state or political system. Within the limits allowed by the ruling elites in socialist countries, sport became an important and legitimate source of national identity. Suddenly, a public space where national symbols could be openly displayed and people could openly express their national aspirations without political consequences was available in the socialist system (Gál, 2011). However, that did apply only in certain cases, as mentioned below.

It is worth noting that while the sporting successes of the state were emphasized as a success of political leaders themselves, sporting failures were on the other hand criticized as a failure of individual or sporting organizations with the effort to distance from it. These failures often lead to subsequent punishment for unsuccessful athletes (e.g. cyclist Jan Veselý after the surrender of the Peace Race, and Czechoslovak football team after the failure at the World Championships in Mexico). Regardless of how real were the performance objectives for athletes. (Slepičková, 2010).

In addition to these rather national impact successes or failures in sports, it is possible to observe their international context. George Orwell said that the rivalry of national representations is a war without shooting (Kobiela, 2011). Therefore it cannot omit some rather episodic impact of international sporting success to the relationship of two states, which have fought so-called Soccer War between Honduras and El Salvador in the late sixties of the twentieth century. On which we can observe the involved audience and its reaction to the success or failure of one or the other team during, and after the match. This has helped various official and unofficial benchmarking and scoring earned achievements. 
For example, the Olympic Games were scored by the rank earned. Media presented a comparison of each country in the numbers of medals and points, which was later used in the various states in socio-political level, as well as in relation to the interpretation of existing social system (Slepičková, 2010). Country rankings in the Olympic Games became a prestigious matter, especially after the introduction of the Soviet Union to the field of international sport in 1952 Olympic Games in Helsinki. In informal classification Soviet Union earned the same number of points as the USA athletes (494) which was a big surprise. Sport has become a prestigious political matter. (Kössl, 1995). It is necessary to recall the great struggle of Western and Eastern bloc, which unleashed right after a massive arrival of athletes of the Soviet Union at the Helsinki Olympics. However, we could note that the increasing successes of athletes from socialist countries often formed adoration monographs, such as publications "Na stupních vítězü" (English - "On the Podium") as a triumph of socialist sport. The driving force were the extraordinary results of athletes from socialist countries at the Olympic Games in Montreal (which were held on the North American continent) and being interpreted as the absolute defeat of the capitalist sport ("Na stupních vitězü", 1980).

\section{METHODS}

For the purposes of this paper we will be working with two pairs of case studies with content similarity. We will mainly point out historical context where sports and political interests have directly intertwined and what was the direct influence of reported events per capita of the country and the consequences of the problem. In the first part, which will focus on political effects on sports within the country, we will discuss national struggle within the former Yugoslavia and Spain. In the first case we will analyze how the sport helped to collapse Federal Republic of Yugoslavia. In the case of Spain, by contrast, will be demonstrated how sport can become the tool to suppress separatist efforts. In the second part of this paper we will present countries gaining or losing prestige before its inhabitants or the whole world via international sporting rivalry. The first analysis will be given to the former Czechoslovakia and its hockey duels with the Soviet Union and so called Kozakiewicz gesture. Closing topic of this paper will be describing the collapse of the Soviet Union and its sports and political consequences.

\section{RESULTS}

The collapse of the former Yugoslavia and the forming of Croatia and other countries of the FRY through their sporting achievements.

In relation to the fall of the Iron Curtain and the end of the Cold War we commemorate the fate of the newly formed European countries. The division of the Federal Republic of Yugoslavia was probably most problematic. After the fall of the Iron Curtain nations united in this republic started to claim independence. Year 1992 was especially crucial in sports events. Three straight major sports events - the Winter and Summer Olympics and the European Football Championship were held. Countries of Croatia and Slovenia already represented themselves independently at the Winter Olympics in Albertville. Bosnia and Herzegovina, Montenegro and Serbia remained under the auspices of Yugoslavia. Macedonia, although already independent, did not participate in the games. Bosnia and Herzegovina had independent representation at the Summer Olympics in Barcelona. Serbia, Montenegro and Macedonia performed together under the name "Independent Olympic Participant". Macedonia was the first individual Olympic representation in the 1996 Olympics in Atlanta, Montenegro and separated Serbia in 2010 at the Olympics in Vancouver. Quite a controversy arose at the European Football Championship in Sweden in 1992, where was the national team of the former Yugoslavia excluded from the final tournament. This representation was also in the same year prevented from playing qualification for the final tournament of the World Cup in the United States in 1994. The reason was also the military conflict. 
The most problematic and the most significant was the separation of Croatian representation of Yugoslavian, which lead to violent conflicts. Riots already took place in 1990, between fans of Dinamo Zagreb (Croatian) and Crvena Zvezda Beograd (Yugoslavian). This moment is by some Croats considered as the beginning of the War of Independence. Football player Zvonimir Boban became a hero when he assaulted a police officer who tried to pacify the rampaging fans of Dinamo (Kuper, 2007). Croatian players still officially belonged to the Yugoslavian representation until 1991, where they still experienced relatively successful performance at the World Cup in 1990 in Italy. However, just before this championship, Croatian fans booed the Yugoslavian team during the national anthem during the final pre-match in Zagreb. Big riots also took place in Split in autumn 1990, during the match between the local team Hajduk Split and Partizan Beograd. A group of fans got on the field and tore the Yugoslavian flag. The match was suspended thanks to this incident. FIFA officially recognized the Croatian national football team in 1992, although the team itself already played the first international match with the USA in autumn, 1990.

International sport has played an important role in the formation and establishment of an independent Croatian state in a global context. Quite controversial step was renaming the biggest Croatian football club Dinamo Zagreb to Croatia Zagreb. This change was based on direct instruction of the former strongly nationalist country's president, Franjo Tudjman. This decision, however, was not accepted entirely positively. The football team became the symbol of the country and it was successfully qualified for the European Championship in 1996 in England where it advanced to the quarterfinals. Even greater success was achieved at the World Championships in France in 1998, where the team finished third and Davor Suker became the top scorer of the championship. Basketball became another equally successful collective sport for Croatia (Levermore, 2004). Croatia advanced to the finals at the Olympic Games in Barcelona and lost with famous American "Dream Team" leaving the Olympics with the silver medal. Another strong side of Croatian sports was tennis. Tennis player Goran Ivanišević, who in the nineties managed to fight his way to the finals three times on Wimbledon $(1992,1994,1998)$ also won this tournament in 2001. The greatest success was achieved by skier Janica Kostelic who earned 4 gold medals for her country at the Olympic Games in Salt Lake City and Torino. World champion five times and winner of the World Cup three times is her credit. Croatia was the most successful country of the former Yugoslavia in the field of sport which was helpful to gain some self esteem for the nation. Thanks to sports successes Croatia became more popular on the map of the world, where it was previously known only as the "battlefield". Croatia is also very proud to honors its athletes. One of the main squares in Zagreb and a sports hall nearby is named by the main successor of the Barcelona Olympics - Dražen Petrović who tragically died.

Very important are the sporting achievements of Serbia, who excelled in basketball competitions, although the Serbian representation was known by the name "Yugoslavia" until 2006. In 1996 Serbians acquired second place at the Olympic Games in Atlanta. In the years 1998 and 2002 they won the world championship, and they also acquired the title "European Champion" in 1995, 1997 and 2001. Significant nationalist subtext has been observed when those triumphs were acquired. Crowds in Belgrade boisterously chanted "Yugoslavia!" Status of "heroes" had been awarded to players of the Macedonian national basketball team, who came fourth in the European Championships in Lithuania 2011. The fourth place was celebrated and taken almost as a victory; the main square in Skopje was overcrowded by people. The fourth place meant a lot to Macedonia. It was the best result in the sports history of the country and also the best ranking of the former Yugoslavian republics at this championship.

The success of each representative team or achievements of individuals was very important in the case of former Yugoslavian republics, especially to strengthen national self-confidence. Yugoslavia had fairly significant sporting achievements in collective sports, which were also inherited by the new formed 
countries, especially by Croatia and Serbia. In Croatia, the meaning of its sports teams played rather important role. In Serbia, the successes after the dissolution of the federation of Yugoslavia were perceived more nostalgically.

The issue of multinational Spain

In a similar situation as the former Yugoslavia is the Spain today. Despite minor difficulties, Spain is still a country managing to keep politics under control of the multinational state unlike Yugoslavia. Spain is a country where ambivalent Spaniards (from different provinces, especially from a wider area of Madrid) live together with Catalans, Basques and other smaller nationalities. Leaving aside the excesses associated with terrorism, purely from a sporting point of view, we can observe the glaring issue of football club FC Barcelona, which is profiled as a Catalan rather than a Spanish club. Also, because there is considerable rivalry between the two biggest football teams - Real Madrid, which represents a centralized Spain, and a synonym of national self-represented team FC Barcelona.

The situation within Spain is even more complicated. For many years, the Basques and Catalans promoted their own football team within the Kingdom of Spain. They wanted to express independence of Spain in their own way. The precedent was to model the United Kingdom, which is also represented by four historic countries. In 1997 Catalans renewed their annual match against foreign rivals (this tradition ended in the mid-seventies). Basques followed this example in 1999. Joseph Guardiola, a former coach and captain of FC Barcelona said that he would prefer to replace the team uniform of the Spanish national football team for the Catalan one. 43,000 spectators came to see the match of the Catalan national team against Yugoslavia at the Olympic Stadium in Barcelona (Maguire, 2002).

However, if we look at the recent sports history, it is Spain who achieved significant sporting successes in the last years. For example, motorsports such as F1 or motorcycle competitions (although only teams are represented). Other sports worth mentioning are tennis (Rafael Nadal, Davis Cup), basketball, but especially football. Spain won the trophy for the last two years of the European Championships (2008, 2012), World Championship (2010) and the success even goes to youth competitions in football (under 19, 20, 21). Therefore, for our analysis we will choose the case of winning team of the FIFA World Cup 2010 and look at its internal structure. This team was composed of both players playing for Real Madrid, as well as for team FC Barcelona. This national representation managed (in a way) to unite ethnically different, heterogeneous and conflicting Spain. A sense of belonging to their country was evident among the people especially during the general celebrations after winning the World Cup. This unity was usually common just to the specific nation within the Kingdom of Spain. Suddenly, players like Carles Puyol and Xabi Alonso have not fought for their Catalan club but for the whole Spain, while their "rivals" of Real Madrid Sergio Ramoz or Iker Casillas have helped them to victory.

Thus, we can say with certainty that the political meaning of this representation was quite significant. The political leaders of the country had to be duly satisfied for the subsequent wave of national pride (although some patriotic Catalans claim that they literally hate the Spanish national team uniform). However, what will happen when the celebrations are over and the triumph becomes ordinary? Right here is probably the root of the problem, after the next four years there will be a new champion and the situation may be reversed. We can also consider the situation if this representation was not so successful. Would the nations of Kingdom of Spain lose their sense of brotherhood then? Therefore, looking for the socio-political sense in this case would be quite difficult. 
Matches of the Czech national ice hockey team and the Soviet Union in 1969 \& Kozakiewicz's gesture. Hockey victory over the Soviet Union in 1969 was one of the biggest sporting and societal events in the late sixties and early seventies in Czechoslovakia. Everything has happened less than a year after the invasion of the troops of Warsaw Pact into Czechoslovakia which stopped the liberalization, destroying the country's only real hope of political change. Defeating the occupying Soviets in Czechoslovakia twice caused a wave of tumultuous celebrations that were not much in the nature of the celebration of sporting success, but had rather strong political subtext. From our point of view, the collision of interests of the state is very remarkable. On the one hand, the national hockey team had to represent the country. On the other hand, it was not to become an instrument of protest against the regime and opposition to the Soviet Union. This leads us to a really simple equation. In this case, the political meaning of the national team was significant, but paradoxically it represented other political ideals than the regime. Czechoslovak players, who represented their socialist homeland, came to the match with covered communist red stars on the Czechoslovak national emblem on their team uniform. They have won the match. From this perspective, it was not the right for the ruling communist government. However, the team fulfilled its social meaning, which meant to express disapproval of most citizens with the occupation of Czechoslovakia by the Soviet Union. These massive celebrations, which grew into protests and spontaneous expression of resistance against the Soviet Union, were used by the state police for further arrests. These protests were one of the starting elements of 20 years long solid phase of socialism, known as "normalization".

During the period of the Iron Curtain a sport became a very powerful political weapon in Poland. Participation at the Olympics in London in 1948 was a symbol of Poland renewed return to the world of sport. The fifties were marked by rigid Stalinization (renaming the clubs names, centralization), and by large influence of Communist rule in sports events in later years (Kobiela, 2011). Expectations of political authorities were supposed to demonstrate superiority of socialist sport over the capitalist one. However, expectations of sports fans were different. Sporting victories over the Soviet Union served as a symbol of retribution for political hegemony of the Soviet Union had a very special value for the fans.

In this sense, the history of polish sport was marked by a major incident at the Olympic Games in Moscow in 1980, which is known as "Kozakiewicz's gesture". After setting a new world record and defeating his Soviet rival Constantine Volkov, Polish pole vaulter Wladyslaw Kozakiewicz pointed towards the audience in Moscow with a victorious look and a mocking gesture on his face. This incident is being compared to a gesture of African-American athletes who protested against racial segregation by saluting on the podium at the Mexico Olympics in 1968 (Kobiela, 2011). After this provocation Kozakiewicz was forced to emigrate to the Federal Republic of Germany. For the Poles, Kozakiewicz's gesture had a similar meaning as the double defeat of the Soviet Union for Czechoslovaks.

Russia and its victories - need of victories in sports for renewing national self-confidence, confrontation with earlier satellites

In this paper we have mentioned the Soviet Union several times as well as the political need to present the country in international sport for purposes of government ideology. Textbook examples are the two former Eastern Bloc countries - the former German Democratic Republic and the Soviet Union. It is astonishing that until the fifties the Soviets paid no attention to the field of international sport in general. That made their arrival even more gigantic. In the following years the Soviets excelled in mostly all popular sports and acquired the most valuable trophies (winning the European Championship in 1960, Ice hockey victory, national rankings at the Olympics). At the time of the Iron Curtain, the Soviets attributed their sports teams' important role in building the confidence necessary for the eternal battle with the United States and Western blocs, the sport was considered as part of the Cold War. However, after the collapse of the union 
Russia (known as Commonwealth of Independent States back in the day) started clearing positions both in the field of diplomatic and military influence, as well as for the international sports. These factors had a negative effect to the Russian national self-confidence. After the collapse of the Soviet union Russia faced a huge population decline, which reduced the number of permanent residents of tens of millions, both by natural decrease and emigration. However, the question remains whether Russians need to acquire national self-confidence in the field of diplomacy or sports. Which of these privileges should be more needed by the people? Would they prefer to see how Russia is once again becoming a diplomatic superpower or would they like to see Russian athletes standing on the podium and stadium echoes the Russian anthem? So the question remains, what kind of acknowledgement the Russian national character needs more, whether recovering the status of "superpower" or returning the international glory of Russian athletes.

Let us return for a moment to the period just after the fall of the Iron Curtain, specifically to the Olympic Games in Albertville and Barcelona. Soviet Union, which at the time was called the CIS (Commonwealth of Independent States), represented unified team. At the Winter Olympics in Albertville this team was the second most successful in the number of medals acquired, at the Summer Olympics in Barcelona by far even the most successful team. A great curiosity is that the team did not have its own national anthem or flag. Olympic anthem and flag served for this purpose. In the community of "united national teams" only Baltic States (Lithuania, Latvia and Estonia) were missing of all former Soviet republics. This act confirmed their independence as well as their active interests in international sports. Even today there is a big rivalry in some sporting events, especially in the case of ice hockey matches of Latvia - Russia and basketball matches of Lithuania - Russia. We can recall the famous victory at the Olympics in Barcelona, where Lithuania defeated the unified team at the battle for third place. This victory was a great satisfaction for Lithuanians, because basketball has been reborn as a country national sport. A similar situation experienced Latvia, where the most popular sport is ice hockey, in 2000 at the World Ice Hockey Championship, hosted by the St. Petersburg, Russia. The Russians were the main favorite at this tournament; they were even considered a 'Dream Team'. However, the 'Dream team' was defeated by the tournament underdog Latvia. After another defeats Russia did not even get into the final play-off. Today this victory is considered as one of the largest in the history of the Latvian sport (Latvian history, 2012).

Russia is therefore currently in a completely opposite situation than its former satellites or involuntarily annexed republics of the Soviet Union. Small countries celebrate victory over their former oppressor, while former superpower is trying to reach its former glory and looks for the causes of defeats by their once obedient republics. In these processes, we can see an interesting link with the geopolitical importance of sports representations in today's world. These fights in many cases exceed their original purpose way beyond sports dimension.

\section{DISCUSSION AND CONCLUSIONS}

The first two case studies showed that the sport in totally different cases intervenes the state functionality and subverts or strengthens its political integrity. Nationalism was the most important in the case of Yugoslavia, especially when the Croats refused to be part of Yugoslavian national team. Subsequent athletic achievements helped to strengthen the position of an independent state, not only in the eyes of Croats themselves, but also in the international arena. On the other hand Spain's ruling elite sees sport as a pretext for maintaining integrity. There is also a big threat in the club FC Barcelona, which supports separatist efforts. In the second pair of analyzes, we must emphasize the situation of smaller countries that through sports confrontations strengthen their self-confidence and dispose of frustrations of political 
subordination. Interesting is also the position of Russia, which, together with the loss of being a superpower began to lose its position on the sports field.

The political purpose of sport can be spontaneous or controlled. Political integrity can consolidate by a common sporting success, as well as by the sporting success 'on demand', as it is known from totalitarian regimes and their strategy for the victory at any cost. Undoubtedly, we must emphasize the transience of sporting success. It is necessary to realize the cycle of events, successes and failures of sport events and the risk of sports disappointments and losses of once gained fame. Political leaders can use sport as an effective weapon that can have its uses in both ethnic tensions, strengthening national self-esteem or even separatistic efforts. Today's political power of sport is slowly shifting to countries like China and other countries in Southeast Asia, South America and Middle East. These countries can through sport gain its place on the so-called world sports map and prove its inhabitants and the rest of the world that their countries are not only economically raising. Because of this phenomenon in different historical periods as a tendency to celebrate the winners and condemn losers, it is expectable that the social and political dimension of success in sports in general will remain for the foreseeable future.

\section{REFERENCES}

1. Budd, A. (2004) Sport and capitalism. In R. Levermore and A. Budd. Sport and international relations: an emerging relationship. London: Routledge.

2. Candian Olympic Team Official Website (2013). 1936 Garmish-Partenkirchen. Retrieved from: http://olympic.ca/games/1936-garmisch-partenkirchen.

3. Coakley J. (2001) Sport in society: Issues and Controversies. Boston: McGraw Hill.

4. Cuhra, J., Ellinger, J., Gjuričová, A. \& Smetana, V. (2006). České země v evropských dějinách, díl čtvrtý. Litomyšl: Paseka.

5. Gál, A. (2011). Society and sport in Hungary: neither with nor without. In S.G. Fölesiné and T. Dóczi (Eds.) The Interaction of Sport and Society in the V4 Countries. Budapest: Hungarian Society of Sport Science, pp.65-84.

6. Jarvie, G. (2006). Sport, Culture and Society: an introduction. London: Routledge.

7. Kobiela, F. (2011). From state socialism to free society: sport in Poland from 1945 until present day. In In S.G. Fölesiné and T. Dóczi (Eds.) The Interaction of Sport and Society in the V4 Countries, Budapest: Hungarian Society of Sport Science, pp.85-94.

8. Kol. Autorů. (1980). Na stupních vítězů - sportovci socialistických zemí na olympijských hrách. Praha: Olympia.

9. Kössl, J. (2008). Vybrané kapitoly z dějin tělesné kultury. Praha: Karolinum.

10. Kuper, S. (2007). Political Football: Zvonimir Boban. Channel 4 News (online). Retrieved from: http://www.channel4.com/news/articles/sports/political+football+zvonimir+boban/1205847.html.

11. Latvian history. Blog at WordPress.com (2012) Retrieved from: http://latvianhistory.wordpress.com/2012/06/09/latvian-national-hockey-team/.

12. Levermore, R. (2004). Sport and international relations: continued neglected. In R. Levermore and A. Budd. Sport and international relations: an emerging relationship. London: Routledge.

13. Maguire, J. (2005). Power and global sport: zones of prestige, emulation and resestance. London: Routledge.

14. Maguire, J. (2002). Sports worlds: a sociological perspektive. Champaign: Human kinetics.

15. Slepičková, I. \& Slepička, P. (2010). Sport a politika. Praha: Univerzita Karlova, Fakulta tělesné výchovy a sportu. 